\title{
INTRODUCING DIGITAL LITERACY SKILLS THROUGH IBL: A COMPARATIVE STUDY OF UG AND PG BUSINESS INFORMATION SYSTEMS STUDENTS
}

\author{
Marie Griffiths \\ Salford Business School \\ University of Salford \\ M5 4WT \\ m.griffiths@salford.ac.uk \\ Maria Kutar \\ Salford Business School \\ University of Salford \\ M5 4WT \\ m.kutar@salford.ac.uk \\ http://www.business.salford.ac.uk/st http://www.business.salford.ac.uk/st \\ aff/MarieGriffiths \\ aff/mariakutar \\ Jamie Wood \\ Religions and Theology \\ University of Manchester \\ M13 9PL \\ jamie.wood@manchester.ac.uk \\ http://manchester.academia.edu/Ja \\ mieWood
}

\begin{abstract}
This paper reports a comparative study of Inquiry-Based Learning (IBL) at Undergraduate (UG) and Postgraduate (PG) levels at a university in the north west of England. Both student cohorts undertook a professional, legal and ethical module centred on IT. This study focuses on how the different student cohorts approached this style of teaching, and how it impacted on overall student engagement throughout the semester. IBL was introduced in the 2009-2010 academic years; to the UG students in the first semester and the PG students in the second semester. Key observations gained from the study were unexpected in that the UG level students fully embraced the IBL approach, they maintained a high attendance level throughout the semester, and all preliminary and formative assessment work/tasks were eagerly completed. Ultimately, this developed students' information literacy skills. PG students enjoyed the in-class IBL activities, but actively avoided module preparation and formative assessment work/tasks, and so minimized their opportunities to develop rich digital literacy skills. This study highlights potential enablers required to employ IBL techniques successfully.
\end{abstract}

\section{Keywords}

IBL approach, digital literacy, information literacy, formative assessment, inquiry based learning.

\section{INTRODUCTION}

The role of rich media environments for student engagement - for example, virtual learning environments (VLEs), emerging technologies such as wikis, podcasting and YouTube - is fast becoming a hot topic in the science of teaching. Educators and researchers are enthusiastic adopters of web 2.0 technologies in the classroom. The project reported in this article aimed to add a further dimension to this pedagogical mix by bringing together authentic teaching environments, immersive virtual worlds, and inquiry-based learning (IBL) to provide a collaborative pedagogical framework to enable students to engage in knowledge building. IBL encompasses approaches to learning that are based on a process of self-directed inquiry or research where the lecturers are facilitators in the process of knowledge whilst the students discover and create the knowledge for themselves and seemed well suited to the objectives of the project.

This study was funded by CILASS (Centre for Inquiry-based Learning in the Arts and Social Sciences), a Centre for Excellence in Teaching and Learning (CETL) at The University of Sheffield as part of a funding stream dedicated to developing and sharing IBL practice across higher education institutions in England and Wales. The research reported in this study centred on how the two different student cohorts approached and benefited from this style of teaching, and on changes in student engagement and motivation during the module. The study was initially concerned with the redevelopment of an existing year two UG module, Professional, Legal and Ethical Studies. Class contact was redesigned to support 31 students in developing skills such as information literacy, collaboration and communication, at the same time as developing students' subject knowledge and disciplinary skills. The developed pedagogical framework was then used to restructure the delivery of the postgraduate (PG) module, Professional Issues in IT to 30 students. The two modules have some common learning outcomes - e.g. Discuss critically the major ethical issues affecting computer professionals both orally and in writing / Discuss critically the relevant legislation affecting computer software 
development and computer and Internet usage. In additional the syllabus for the two modules include similar topics such as the ethical issues of technology in the workplace and in society, information privacy, surveillance, and professional practice in the IT industry. IBL was introduced to the UG students in the first semester of the 2009-2010 academic year and to the PG students in the second semester. Each module is a single semester module. The timing of the introduction of the students to IBL was determined by programme structures and provided the research team with valuable opportunities for refection, enabling comparisons to be made between the two student groups. This study allowed two very different students cohorts, but with a comparable sample size, to experience IBL of a similar topic area, delivered by the same tutors/lecturers, in the same institution, so allowing the observation of what enablers may be needed to achieve successful IBL.

This article begins with a survey of the literature on IBL, including an in-depth review of the literature pertaining to the application of IBL in the module topic area. This is then followed by an account of the research strategy developed for this study. The case data is structured into two sections: the UG case study, followed by the PG case study. A comparison of these two cohorts then forms a discussion section and limitations of the study are considered. The article closes with a section that summarises the project's findings and offers a number of suggestion regarding directions for future work.

\section{INQUIRY BASED LEARNING}

Inquiry-Based Learning (IBL) has become an increasingly popular approach to teaching and learning in higher education over the past decade. IBL is well-aligned with social constructivist epistemologies, which emphasise the importance of the active and experiential construction of knowledge by the subject and the fundamentally social nature of this process (Dewey, 1938; Vygotsky, 1962; 1978). Inquiry- and research-based pedagogies have emerged as approaches which correspond well to such processes of knowledge construction and evidence suggests that students benefit from engaging in this form of learning in terms of skills and knowledge development and preparation for life after university (Brew, 2006).

IBL is a student-centred and active form of learning which engages students, individually and collaboratively, in self-directed research into the subject matter and problems of their academic and professional disciplines (Kahn \& O'Rourke, 2004). Although IBL is related to problem-based learning (PBL), an approach in which students are presented with a problem, to which there is usually a known solution, and are guided through the process of addressing that problem by a facilitator (Barrett, 2005), IBL is usually more open-ended than PBL. This means that in IBL students are generally given greater freedom to define for themselves both the questions they will address and the process by which they will engage with those questions. Although there are variations according to discipline, level and the teaching philosophy and approach of individual academics (Wood and Levy, 2009), IBL is essentially question-driven, while PBL is problem-driven. In terms of similarities with PBL, the inquiry-based process of student learning is often supported by a facilitator and involves a significant element of collaborative working. Some criticism of IBL, PBL and other constructivist forms of teaching and learning has focussed on the perception that they fail to provide students with sufficient guidance and support for their learning (e.g. Kirschner et al., 2006). However, such criticism is founded on a misunderstanding of the fundamental basis of such pedagogies: the intention is not to leave students to fend for themselves, but to provide them with a structured and supportive environment in which they can carry out their work: it is poor teaching that results in students receiving insufficient support and guidance, not inquirybased or problem-based pedagogies as such.

Developing the disposition towards 'self authorship', an outlook that involves the questioning of trusted authorities, moving away from comfortable ways of viewing the world towards exploring multiple perspectives and towards constructing one's own beliefs and values (Baxter-Magolda, 2009) is increasingly seen as one of the most desirable outcomes of a university education. Most outcomes of higher education, such as intercultural maturity, critical thinking, decision-making, an ethical outlook, and responsible citizenship, hinge on the capacity for self-authorship and it has been suggested that IBL and research-based pedagogies are successful in developing in students such knowledge, skills and dispositions (Smith, 2003; Brew, 2006), all of which are essential to negotiating a world that is typified by 'super-complexity' (Barnett, 1999, 2000; Levy, 2007). Recent research on IBL across a range of arts and social science disciplines at the University of Sheffield has suggested that such positive outcomes are felt especially strongly if they are experienced at the beginning of students' experience at university: that is, in the first year, rather than at the culmination of their studies, as it traditionally supposed (Levy and Petrulis, forthcoming, 2012). 
Due to the centrality of the research process - searching, finding, evaluating, using and communicating information - to IBL pedagogy, particular attention is often given to the development of students' information literacy competencies (McKinney and Levy, 2006). According to the Chartered Institute of Library and Information Professionals, "information literacy is knowing when and why you need information, where to find it, and how to evaluate, use and communicate it in an ethical manner" (CILIP, 2004). Alongside the requirement that students following IBL processes access and use information ethically, and the resultant development of students' competency and disposition to act in an ethical manner, there has been significant pedagogic work using PBL in computer science education and IBL within the discipline area of legal and ethical studies.

\subsection{IBL in Computer Science}

Project-based learning is well-established in computer science education. By encouraging students to engage collaboratively and actively with the problems of their discipline, group project work is judged to prepare students effectively for professional practice (Fincher and Petre, 1998). Such approaches closely resemble inquiry- and problem-based teaching and learning strategies. It is therefore unsurprising that IBL and PBL have been adopted successfully in a number of different contexts in computer science education (for a survey see Gordon and Brayshaw, 2008). For instance, a hybrid approach to PBL was adopted at the National University of Ireland at Maynooth to encourage a deeper approach to learning in first year student groups. Students were allocated into tutorial groups of 5 to 7 students and these groups worked actively and collaboratively on problems while attending an accompanying series of lectures which coupled the delivery of subject content with more active learning approaches (O'Kelly, 2005). At the same institution a PBL approach has been adopted as a method of engaging groups of 4 to 5 third year software engineering students with the kinds of real-world problems that they would encounter in an industry context. Students worked collaboratively on their problems with the help of a facilitator when necessary; at the end of the course they presented, demonstrated and defended the work they had carried out. At the same time as working on their problems collaboratively, the students completed reflective diaries on an individual basis:

"as a forum for the learner to clarify their own thoughts, practice informal writing, develop independent, critical thinking skills and become aware of the learning process occurring. The journal was also valuable as an assessment tool, to distinguish individual learning and achievements from those of the team." (Delaney and Mitchell, 2005, p. 70)

Tutorials were set up in order to provide the students with necessary information to fill the gaps in their subject knowledge. The questions for these tutorials were set by the students, who were responsible for identifying the gaps in their knowledge; the facilitators provided the material to enable the students to fill those gaps. The course leaders judge that their approach had a positive impact upon student learning:

"Our classroom offers an interactive learning environment that fosters student learning in collaboration with each other and with the facilitators. The course brings software engineering alive and in so doing motivates students to become active and self-directed learners." (Delaney and Mitchell, 2005, p. 73)

\subsection{IBL in Legal and Ethical Studies}

Ethical training is necessary to equip students to engage with the content of their disciplines in a social context, to allow them to contribute responsibly to building and constructing knowledge, and to prepare them to meet the challenges of globalisation and to develop their notions of social responsibility, including the use of technology in an ethical manner (Woodcock, 2000; Smith, 2002; Hicks et al., 2004; Harris, 2006; Chan, 2010). A number of educational theorists argue that inquiry-based forms of teaching and learning are particularly well-suited to inculcating such capacities in students.

Increasingly, inquiry-based ethics is being integrated into educational curricula across a range of disciplines. For example, a course entitled "What is Science For?" is completed by all second year students in the Life Sciences curriculum at the University of Manchester. Students are engaged with relevant ethical issues through a combination of face-to-face and online teaching, small group work and large group lecture-style sessions, and supplied reading materials and student-led discussions (Chan, 2010).

In reviewing the adoption of PBL in legal education in New Zealand, Mackinnon (2006) argued that problembased pedagogies develop students' reflective capacities alongside their disciplinary knowledge and skills and therefore that PBL should be implemented more widely:

"Reflexivity contributes to humanist as well as to legal solutions to complex human problems and is essential to professional citizenship participation in the globalising market and society at a time of transition from a work society to a risk society." (Mackinnon, 2006, p. 18) 
Legal educators have been similarly active in implementing problem-based and inquiry-based approaches in curricula in the UK. In the Law School at the University of Sheffield, for example, students across all undergraduate (UG) levels have been engaged in individual and collaborative research projects, often supported through the institutional VLE and Web2.0 technologies, to develop their information literacy skills, their understanding of the research processes involved in legal studies and their knowledge of the discipline (Semmens and Taylor, 2006; Davis and Loasby, 2009). Using an approach adapted from the teaching of law, students of social work at the University of Liverpool are engaged actively with the content and working of social work law, developing their professional skills in the process:

"The case scenario, which describes a situation inviting social work intervention and tells a story unfolding over time, requires students to construct their own analytical framework, through addressing definitional and problem-solving questions." (Braye et al., 2003, p. 481).

In summary, IBL is well suited to legal and ethical studies in terms of the processes it involves and outcomes of learning which it promotes, while similar pedagogic approaches, mainly PBL, have been adopted in the area of computer science education with some success.

\section{Methodology}

The research strategy for the project which is the subject of this article was shaped by a number of conditions placed by the funding body CILASS and also by the host institution. Funding was provided to facilitate the restructuring of a module to implement an IBL approach. The funding body fixed a time frame to a one-year period from May 2009. As part of the funding conditions a 'theory of change' (ToC) project evaluation methodology was used. The ToC approach to impact evaluation is an adaptation of Theories of Change programme evaluation (Connell and Kubisch, 1995) combined with the use of EPO (Enabling, Process and Outcome) Performance Indicators (Helsby and Saunders, 1993). The CILASS ToC approach works as follows. Through backward mapping, a causal narrative or informal 'theory' is established which identifies evaluation indicators and becomes the basis for an evaluation plan. For example, 'to achieve the desired impact on student learning experiences, the outcomes of an initiative need to be $\mathrm{x}, \mathrm{y}$ and $\mathrm{z}$; in order to achieve these outcomes, the processes or activities $\mathrm{a}, \mathrm{b}$ and $\mathrm{c}$ need to happen; in order to carry out $\mathrm{a}, \mathrm{b}$ and $\mathrm{c}$, the enabling factors and resources $d$, e and $f$ are required'. The ToC approach is operationalized by developing an evaluation plan that allows the project team to test, via a variety of means (i.e. to triangulate results), each of these indicators. Project leaders can choose whatever means they wish to gather this data, but perhaps the most popular have been: pre- and post-module questionnaires or focus groups with students; reflective interviews with module staff; and observation of classes and/or student work. Once the data has been collected it can be used to evaluate the project according to each of its ToC indicators and to enable comparison across projects. It should be stressed here that the intention of the ToC is to learn about the process of educational change rather than to check up on project leaders. A fortuitous side-effect of the ToC process is that it can generate a large amount of targeted and rich data which can be tied with relative ease to educational research projects (indeed, this was a stated aim of a number of CILASS-funded ToCs).

In addition to adopting the CILASS ToC approach, ethical approval was required from the host institution. This was particularly significant as students were participants in the research process and so it was important to ensure that all students were willing contributors and felt comfortable with the process. Research design required careful attention to gaining informed consent, and in particular to ensuring that student feedback on the process was clearly dissociated from their academic performance on the module. The rationale for applying for the funding stemmed from the overwhelmingly positive response to a sample of IBL-type activities that had been used with the previous year's student cohort. A focus group of 12 formed from a sample of these students helped shape the redesigned module for the following year (Stewart et al., 2006). An action research methodology was adopted, enabling iterative interventions/improvements throughout the semester (Oates 2006), this was due to the predicted, empowering characteristics of these alternative teaching methods and the aim was to react immediately and to respond to student feedback. The evaluation of the IBL approach throughout the module was a priority and a structure was scheduled to administer three anonymous evaluation questionnaires. Doing this part way through the module enabled evaluation of the IBL approach at an early stage and meant that adjustments could be made to teaching strategies and IBL activities as required. The students favoured more practical sessions outside the boundaries of the classroom so activities were redesigned to accommodate this. For the PG cohort, they found group work involving primary and secondary data collection, analysis and presentation of findings within a strict timeframe was challenging and informative. More of these styles of activities were designed into the module. The final evaluation activity was a focus group session, which took place once all teaching and assessment activities had been completed. The focus group of 12 students was recorded and transcribed. A dissemination strategy also formed part of the 
research methodology, including delivery of a workshop on IBL for staff across the institution.

\section{UG CASE StUdY}

The year 2 UG module of 31 students was delivered over a 12 week teaching semester. The structure outlined in figure 1 was supplemented by sessions to introduce the module and IBL, and on information literacy and mind mapping. The information literacy session was designed and delivered by the subject librarian, maximizing use of existing institutional resources and ensuring that information literacy was not seen purely as a module specific skill. The institution provides information literacy training to incoming year 1 UG students, but it was felt that it was appropriate to provide additional training at this stage to enable students to further develop these skills at a point where they could build on the experience of their first year of study. This corresponds well with constructivist pedagogies, which suggest that providing students with the opportunities to develop skills in a context which is directly related to the educational tasks in which they are engaged is far more beneficial to student learning than providing training in specific skills without aligning it with the overall pedagogic approach (McKinney and Levy, 2006). In other words, in the context of this module, the students were more likely to develop their information literacy skills if the activities which develop those skills were closely integrated with the inquiries they were undertaking; otherwise, students are much less likely to see the relevance and buy into the approach that is being adopted.

The module syllabus was divided into inquiries, presented to the students as activity blocks. Each inquiry was composed of a trigger activity designed to lead to a body of knowledge, sessions in which the topics were explored in depth, and a synthesis session. Students were provided with a limited set of resources on the topic at the start of each inquiry. Trigger activities required students to engage in activities outside the classroom which were documented using rich media resources and shared with the cohort via the VLE. These formed a starting point for in-class discussions and activities, and after each synthesis session additional resources were made available as necessary on the VLE to supplement those provided by the students.

IBL Schedule: each activity ran for 3 week blocks

\begin{tabular}{|c|c|}
\hline Activity/Inquiry 1 & CCTV and Freedom of Information \\
\hline Trigger Activity & $\begin{array}{l}\text { To be captured on film and make a subject access request } \\
\text { under the Data Protection Act. }\end{array}$ \\
\hline $\begin{array}{l}\text { Demonstration of lesson } \\
\text { learned }\end{array}$ & $\begin{array}{l}\text { Each team was expected to contribute evidence of the } \\
\text { activity a shared area on the VLE. They were encouraged to } \\
\text { develop a creative digital artefact (presentation/prezi, } \\
\text { photographic portfolios, video diaries / weblogs, electronic } \\
\text { posters). }\end{array}$ \\
\hline Activity/Inquiry 2 & Privacy \\
\hline Trigger Activity & $\begin{array}{l}\text { Students were asked to evaluate their digital footprint, find } \\
\text { out what databases their details are stored on, and } \\
\text { investigate relevant current and proposed legislation. }\end{array}$ \\
\hline $\begin{array}{l}\text { Demonstration of lesson } \\
\text { learned }\end{array}$ & $\begin{array}{l}\text { Teams were expected to provide details of their findings, } \\
\text { their digital footprints, and the results of their research into } \\
\text { databases to a shared area on the VLE. }\end{array}$ \\
\hline Activity / Inquiry 3 & IPR and Creative Commons \\
\hline Trigger Activity & $\begin{array}{l}\text { Investigate Creative Commons licensing and Intellectual } \\
\text { Property Rights (IPR). Conduct vox pops and create a "How } \\
\text { to Guide' for fellow students, upload CC licensed media to } \\
\text { Flickr or similar demonstrating the work. }\end{array}$ \\
\hline $\begin{array}{l}\text { Demonstration of lesson } \\
\text { learned }\end{array}$ & $\begin{array}{l}\text { Each team was expected to contribute evidence of the } \\
\text { activity a shared area on the VLE. They were encouraged to } \\
\text { develop a creative digital artefact (presentation/prezi, } \\
\text { photographic portfolios, video diaries / weblogs, electronic } \\
\text { posters). }\end{array}$ \\
\hline
\end{tabular}

Figure 1: IBL Schedule for UG Cohort 
At the end of the activity blocks an assessment expo was held in which students had to present a digital artefact which they had developed to showcase their work on aspects of surveillance society. A digital artefact included (but was not restricted to) presentation, prezzi, portfolio, video or website. All students were required to demonstrate their work at the expo, both to staff and to other students. The final component of the assessment was an examination which assessed both information literacy skills and subject knowledge. All students in the cohort passed the module, in comparison with the previous year where $84 \%$ of students passed the module, when they were being assessed against the same learning outcomes.

Student engagement with the module was very high from the outset. Despite being timetabled for late Friday afternoon, attendance was very high throughout the module and students contributed well, both to the in-class discussions and to the shared space on the VLE. This enabled us to make informed judgements on the progress of the students as the module progressed. The anonymous evaluation questionnaires which were administered at the end of each inquiry indicated a high level of satisfaction. These factors meant that few changes to the approach were required as the module progressed. The data indicate that the students' satisfaction was increasing as they progressed through each activity (see Figure 2). It was clear that students were accessing appropriate resources and that their knowledge and skills were developing well. This was evidenced by the very high standard of work produced for the expo, with students also performing very well on the exam.

\begin{tabular}{llllllll}
\hline \multicolumn{7}{c}{ How satisfied were you with this module? } \\
\hline & $\begin{array}{l}\text { Extremely } \\
\text { satisfied }\end{array}$ & $\begin{array}{l}\text { Very } \\
\text { satisfied }\end{array}$ & Satisfied & Neither & Dissatisfied & $\begin{array}{l}\text { Very } \\
\text { dissatisfied }\end{array}$ & $\begin{array}{l}\text { Extremely } \\
\text { dissatisfied }\end{array}$ \\
$\begin{array}{l}\text { Activity } \\
1\end{array}$ & 1 & 7 & 4 & 3 & 0 & 0 & 0 \\
$\begin{array}{l}\text { Activity } \\
2\end{array}$ & 4 & 8 & 5 & 3 & 0 & 0 & 0 \\
Activity & 7 & 8 & 2 & 0 & 0 & 0 & 0 \\
3 & & & & & & & 0
\end{tabular}

Figure 2: Student Evaluation Questionnaire Data

\section{PG Case Study}

When designing the approach to the PG module, some changes were made to reflect that this was a Masters level module. Our expectation was that the students would be more motivated at this level to take control of their own learning, and that, having completed a Masters level research methods module, activities based around academic research would be appropriate. This module followed a similar structure to the UG one outlined above, with inquiries based around the topics of information governance, privacy and digital identity, and information ownership. As with the UG cohort, an introductory session provided an introduction to IBL. Separate information literacy sessions were not provided as students had undertaken these in the previous semester. A key difference was that the trigger activity for the first inquiry was based around guided 'academic' pieces of work rather than an off-campus activity. In an early discussion session the group was asked to design and implement a study investigating the Data Protection Act. They also contributed to the design of a piece of research using Freedom of Information requests, and developed a group response to a current consultation from the Office of the Information Commissioner.

The response to the module was less enthusiastic than for the UG cohort. Attendance from the 30 student cohort was less good, and although students contributed well during the sessions they did not engage with the weekly independent activities at first, with little contribution to the shared space on the VLE. Students seemed reluctant to collaborate although feedback for the evaluation questionnaires suggested that they were enjoying the module 'Practical session fun and engaging' and 'I couldn't ask for a more or a better way of learning'. ${ }^{1}$ It was felt that the approach required adaptation if it was to be successful and we were concerned that student learning would be negatively impacted if the lack of engagement was allowed to continue. A decision was

\footnotetext{
${ }^{1}$ Italicised text shows verbatim comments from students provided through either the student evaluation questionnaire or the focus group
} 
made to adapt the activities in order to encourage engagement, with tasks to be completed immediately. Therefore, at the start of the second inquiry we implemented an 'Apprentice' style activity, which placed greater emphasis on students defining their own questions for exploration, based on topic areas which had been provided to them. Students were briefed on a task at the start of a 3 hour teaching block, and asked to work in groups over the first two hours to investigate a topic and produce a short presentation. They were provided with video cameras to record their activities. Each group was given a different theme relating to the topic. They presented to the rest of the group in the final hour of the session. Students were encouraged to improve their presentations after the sessions and upload them to the VLE. This more pressurised approach to the tasks proved to be much more successful than the previous tasks and the level of engagement increased considerably - 'It is certainly not for the faint hearted but it was a lot of fun and informative!! Just keep the pace on and thanks for resources and knowledge transferred'. Another student comments on the potential of transferrable skills he has gained 'Engaging students and making us all work under pressure with time limits will be useful experience fro dissertation'

However, students remained reluctant to contribute to additional collaborative tasks such as uploading to and summarising relevant papers in the VLE unlike the UG students who presented a mature attitude to the collaborative working 'I enjoyed working as part of a team' and sharing of resources 'the weekly artefact brought new ideas in to the course'

This module also culminated in an assignment expo, this time for group work, which was supplemented by an individual essay assignment. Some of the work produced was of an excellent standard, including good quality primary research. However this was less consistent across the cohort. Overall 91\% of students passed the module at the first attempt. Feedback suggested that students enjoyed the module, particularly the 'Apprentice' style sessions, and that they felt they had learned well. Despite this, there were concerns that they had not been provided with enough material (although a considerable number of resources were provided via the VLE at the end of each inquiry). Overall, there seemed to be a lack of recognition that students could learn more effectively using this approach and while student feedback indicated that they would retain the activities, they would prefer this to be supplemented by more traditional teaching approaches such as lectures. Reflection on the overall process suggests that the students benefited much more from being encouraged to frame their own questions to be investigated, rather than being guided towards specific inquiries.

\section{Discussion}

Use of an IBL approach across the two modules produced surprising results. The expectation prior to the modules was that PG students would be more motivated and disciplined in their approach to the module. Whilst there had been concern when first using the approach with UG students, that students may be reluctant to take responsibility for their learning and that they might not engage with the approach or access appropriate resources, these fears proved unfounded. The focus group indicated that students felt they had benefited considerably from the collaborative approach, which both motivated them to learn and provided them with useful additional resources. There was evidence that they felt the need to produce work of a higher standard as it was to be shared with the group, and also that they were learning more deeply. One student stated that in the exam they found it easy to remember relevant work being presented by other students during the sessions. Overall the students thrived with the additional responsibility and IBL seems to have been very successful at this level. In contrast the PG cohort required considerably more encouragement and guidance to take responsibility for their learning. It is clear that the approach was more successful when inquiries required students to frame their own questions, but even once this had been adjusted many students remained reluctant to engage fully or to collaborate.

Reflection on differences between the cohorts indicates that there are a number of factors beyond module design which may have influenced the relative success of this approach. These differences are summarised in figure 3.

\begin{tabular}{|c|c|c|c|c|c|c|}
\hline & Nationality & $\begin{array}{l}\text { Group } \\
\text { cohesion }\end{array}$ & $\begin{array}{l}\text { Team } \\
\text { working }\end{array}$ & Presentation & Tutor Factor & $\begin{array}{l}\text { Literacy } \\
\text { Training }\end{array}$ \\
\hline $\begin{array}{l}\text { UG Cohort } \\
31\end{array}$ & $\begin{array}{l}\text { Mainly } \\
\text { national }\end{array}$ & $\begin{array}{l}\text { More } \\
\text { cohesive }\end{array}$ & $\begin{array}{l}\text { Have } \\
\text { extensive }\end{array}$ & $\begin{array}{l}\text { The group } \\
\text { often present }\end{array}$ & $\begin{array}{l}\text { Tutors know } \\
\text { the group }\end{array}$ & $\begin{array}{l}\text { Specifically } \\
\text { designed }\end{array}$ \\
\hline
\end{tabular}




\begin{tabular}{|c|c|c|c|c|c|c|}
\hline students & students & $\begin{array}{l}\text { group - } \\
\text { together for } \\
\text { a full } \\
\text { academic } \\
\text { year prior } \\
\text { to the } \\
\text { module. }\end{array}$ & $\begin{array}{l}\text { experience of } \\
\text { working in } \\
\text { teams } \\
\text { together. }\end{array}$ & $\begin{array}{l}\text { their work in } \\
\text { front of each } \\
\text { other. }\end{array}$ & $\begin{array}{l}\text { well and } \\
\text { have taught } \\
\text { them on } \\
\text { other } \\
\text { modules in } \\
\text { previous } \\
\text { year. }\end{array}$ & $\begin{array}{l}\text { training } \\
\text { session } \\
\text { delivered by } \\
\text { literacy } \\
\text { specialist. }\end{array}$ \\
\hline $\begin{array}{l}\text { PG Cohort } \\
30 \\
\text { students }\end{array}$ & $\begin{array}{l}\text { Mainly } \\
\text { Internationa } \\
\text { I students }\end{array}$ & $\begin{array}{l}\text { Together } \\
\text { for one } \\
\text { semester, } \\
\text { still forming } \\
\text { bonds }\end{array}$ & $\begin{array}{l}\text { Have } \\
\text { minimal } \\
\text { experience of } \\
\text { working } \\
\text { together as } \\
\text { teams. }\end{array}$ & $\begin{array}{l}\text { Have only } \\
\text { presented their } \\
\text { work in front of } \\
\text { each other a } \\
\text { couple of } \\
\text { times }\end{array}$ & $\begin{array}{l}\text { The first time } \\
\text { the tutors } \\
\text { have met the } \\
\text { group }\end{array}$ & $\begin{array}{l}\text { A mandatory a } \\
\text { research skills } \\
\text { module } \\
\text { delivered in } \\
\text { the first } \\
\text { semester. }\end{array}$ \\
\hline
\end{tabular}

Figure 3: UG and PG Comparisons

\subsection{Nationality}

The differing backgrounds of students may have been a contributing factor. The PG cohort was made up of a majority of International students from a variety of regions. These students have extensive but differing previous experience of $\mathrm{HE}$ pedagogies, with many used to very traditional teaching models where there is a reliance on information transmission from lecturer to student. Such students are often reluctant to present their own opinions or to be critical of the work of others and there may be less emphasis on collaboration and group work. This observation corresponds very well to research which has been undertaken into international students' perceptions of engagement in PBL, which reports that although students and staff benefitted considerably from PBL, prior learning experiences were significant inhibitors to student engagement with the process of learning, (Huang, 2005). By contrast the UG cohort, with less experience of HE, may have been more open to different pedagogies.

\subsection{Group Cohesion}

The students on the UG cohort had worked together for a year previously, with many modules requiring intensive group work. As a result, students knew each other well and had bonded as a group. The students in the PG cohort, although in their second semester, had had less time to develop these bonds, and as with many mature students, displayed greater independence.

\subsection{Team Working}

The students on the UG cohort had worked together in teams on many occasions during their first year. Thus, whilst they were typically younger students and had less overall team working experience, they were well grounded in academic team working. The PG group may have had more team working experience in an employment setting but were less used to academic team work. It was clear from their response to the 'Apprentice' style tasks that the students had effective team working skills, but it seems likely that they had little experience of applying these in an academic context. This is backed up by research into student openness to group working in the Geography discipline which has suggested that previous experience of group work is important in ensuring and supporting student engagement in such activities (Chappell, 2006; Pawson et al., 2006).

\subsection{Presentation}

UG students have presented in front of each other regularly in contrast to the PG cohort.

\subsection{Tutor Factor}

The two lecturers that facilitated the teaching on both modules had taught the UG students during their first year and knew the group well at the start of the module. This influenced interactions with the cohort at the start of the module and may have led to greater levels of trust from the students. It was more difficult to work 
with the PG cohort in the initial stages. This could perhaps be addressed with a more extensive ice-breaking session in the future.

\subsection{Information Literacy Training}

The UG students attended an information literacy skills session specifically designed and delivered by a Library Information Specialist. The students were hesitant about attending this session but the skills gained proved invaluable throughout the module and beyond. One student was surprised that there were other resources besides Google! However there was a genuine surprise of how useful the session was 'The workshop in the library that was quite good!'. The PG students were not offered an information literacy skills session as it was assumed that as they had undertaken a Research Methodology Module in the first semester there would have been duplication of what they had already experienced. This will be reviewed in subsequent iterations.

\subsection{Modes of Inquiry Based Learning}

Research which has been carried out at the University of Sheffield into first year students' experiences of research and inquiry in their disciplines has suggested that providing students with opportunities to engage in open inquiries at the start of their studies impacts positively on their conceptions of research and knowledge building (Levy and Petrulis, forthcoming, 2012). Based on this research, four 'ideal type' modes of IBL were identified. They are labelled Identifying, Pursuing, Producing and Authoring on Figure 4 below and represent the three main factors of pedagogical design: "the status of student inquiry in terms of knowledge-orientation (vertical axis); where primary responsibility lies for establishing the inquiry question or theme (horizontal axis); the level of 'process support', or guidance and structure, provided (mapped on to each quadrant)" (Levy, 2009).

\section{Figure 4: Modes of Inquiry-based Learning (Levy 2009)}

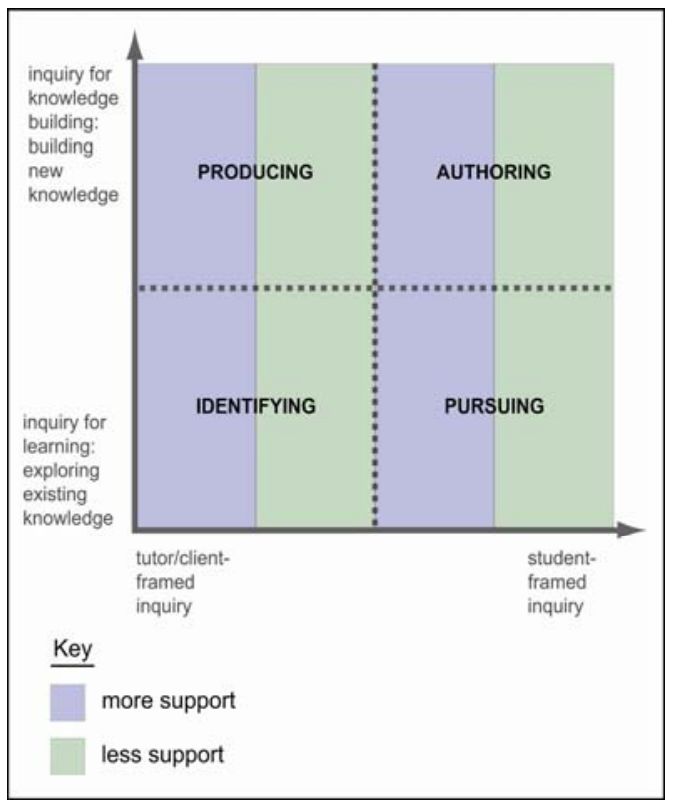

Authoring: Inquiry tasks are designed to encourage students to explore their own open questions, problems, scenarios or lines of inquiry, in interaction with a knowledge-base ('how can I answer my open question?').

Producing: Inquiry tasks are designed to encourage students to explore open questions, problems, scenarios or lines of inquiry, framed by teachers, or others such as an external 'client', in interaction with a knowledge base ('how can I answer this open question?').

Pursuing: Inquiry tasks are designed to encourage students to explore a knowledge-base actively by pursuing their own questions, problems, scenarios or lines of inquiry ('what is the existing answer/response to my question?').

Identifying: Inquiry tasks are designed to encourage students to explore a knowledge-base actively in response to questions, problems, scenarios or lines of inquiry framed by teachers ('what is the existing answer/response to this question?').

The approach adopted in the modules described in this article maps very well against the 'producing' quadrant on the above diagram. The overall inquiries were framed by the tutors, although students were given a great deal of freedom in how to pursue their inquiries (with the exception of the first PG inquiry) and in some cases were addressing research questions which they had established for themselves. In creating the shareable online resources for assessment and conducting their own primary research, students were experimenting with knowledge building. Students were given support and direction from the tutors, particularly at the outset, as would be expected if the students were unfamiliar with IBL approaches. The correlation between the Sheffield research and the findings of this article are important. It provides evidence to suggest that the adoption of similar approaches more broadly in higher education could have important benefits in developing 
students' attitudes towards more student-directed forms of inquiry and knowledge building at the start of their university education - 'because we actually did it (the activity) we now know about it - if you told use about it , it would be like going in one year and out the other'. Hopefully, this would prepare them effectively for the larger-scale inquiries that they encounter at higher levels of study.

\section{CONCLUSIONS AND FutURE WORK}

As was noted in the literature review of IBL, research has suggested that students respond positively and benefit in terms of the development of knowledge, skills and dispositions if they are given opportunities to engage in open-ended research activities early in their time at university, rather than waiting for final year and PG levels (Levy and Petrulis, forthcoming, 2012). The findings of this study support such propositions, but may allow further speculation. They suggest that, given the right conditions and support, students at earlier stages can be disposed more openly towards open-ended and knowledge-building inquiries than PG students. Such openness is likely to lead to greater engagement in the subsequent inquiries. This raises the issues of whether the PG students would have been more engaged with IBL if they had been prepared for it at earlier levels and of how important the specially designed literacy session was for underpinning and developing an effective IBL ethos. This will be addressed in future delivery of the module. Having received such a positive response overall from the PG and UG students in this study, supported by improved pass rates, the intention is to deliver challenging and pertinent IBL activities in future teaching.

\section{REFERENCES}

1. Barnett, R. (1999), Realizing the University in an Age of Supercomplexity (Buckingham: SRHE and Open University).

2. Barnett, R. (2000), 'University knowledge in an age of supercomplexity', Higher Education, 40 (4), 409422.

3. Barrett, T. (2005), 'Understanding Problem-Based Learning', Handbook of Enquiry and Problem-Based Learning. Irish Case Studies and International Perspectives, T. Barrett, I. Mac Labhrainn and H. Fallon, eds. (Dublin: AISHE), pp. 13-25 [online: http://www.aishe.org/readings/2005-2/chapter2.pdf; accessed 09.06.2010].

4. Baxter-Magolda, Marcia B. (2009), 'Educating Students for Self-Authorship: Learning Partnerships to Achieve Complex Outcomes', The University and Its Disciplines: Teaching and Learning Within and Beyond Disciplinary Boundaries, C. Kreber, ed. (Routledge: New York-London), pp. 143-156.

5. Braye, Suzy, Lebacq, Marie, Mann, Frances and Midwinter, Elly (2003), 'Learning social work law: an enquiry-based approach to developing knowledge and skills', Social Work Education, 22 (5), pp. 479492.

6. Brew, A. (2006). Research and teaching: Beyond the divide. Basingstoke: Palgrave Macmillan.

7. Chan, Sarah (2010), 'What is Science For? Incorporating Ethics Education into the Life Sciences Curriculum at Manchester', Case Studies: CEEBL-Supported Projects, 2008-10, A. Aubrey, T. Chilton, K. Comer, F. C. Manista, Norman J. Powell, eds. (Manchester: Centre for Excellence in Enquiry-Based Learning, University of Manchester), pp. 138-144 [online at: http://www.campus.manchester.ac.uk/ceebl/projects/casestudies/92.pdf; accessed 19.06.2010].

8. Chappell, A. (2006). 'Using the 'Grieving Process' and learning journals to evaluate students' responses to problem-based learning in an undergraduate geography curriculum', Journal of Geography in Higher Education, 30 (1), pp. 15-31.

9. CILIP: Chartered Institute of Library and Information Professionals (2004), 'Information Literacy: Definition', [online at: http://www.cilip.org.uk/get-involved/advocacy/learning/informationliteracy/Pages/definition.aspx; accessed 19.06.2010]. 
10. Connell, J.P., Kubisch, A.C., Schorr, L.B., Weiss C.H. (1995). New Approaches to Evaluating Community Initiatives (Vol. 1) (Washington, DC: The Aspen Institute).

11. Davis, F. and Loasby, I. (2009), 'I Love Legal History: web 2.0 and the teaching of law', Journal of Commonwealth Law \& Legal Education, 7 (1), pp. 19-36.

12. Delaney, Declan and Mitchell, George (2005), 'Tutoring project-based learning: a case study of a thirdyear software engineering module at NUI, Maynooth', Handbook of Enquiry and Problem-Based Learning. Irish Case Studies and International Perspectives, T. Barrett, I. Mac Labhrainn and $\mathrm{H}$. Fallon, eds. (Dublin: AISHE), pp. 66-75 [online: http://www.aishe.org/readings/2005-2/chapter7.pdf; accessed 19.06.2010].

13. Dewey, J. (1938). Logic: The theory of inquiry (New York: Holt).

14. Fincher, S. and Petre, M. (1998), 'Project-Based Learning Practices in Computer Science Education', 28th Annual Frontiers in Education (FIE'98), vol. 3, pp. 1185-1191 [online: http://fieconference.org/fie98/papers/1175.pdf; accessed 11.06.2010].

15. Gordon, Neil and Brayshaw, Mike (2008), 'Inquiry based Learning in Computer Science teaching in Higher Education', ITALICS, 7 (1), pp. 22-33 [online at: www.ics.heacademy.ac.uk/italics/vol7iss1/pdf/Paper2.pdf; accessed 19.06.2010].

16. Harris, James K. (2006), 'Ethical perspective in information security education', Issues in Information Systems, 7 (1), pp. 179-181 [online at: http://www.iacis.org/iis/2006_iis/pdfs/harris.pdf; accessed 11.06.2010].

17. Helsby, G. and Saunders, M. (1993). 'Taylorism, Tylerism and performance indicators: defending the indefensible', Educational Studies, 19 (1), pp. 55-77.

18. Hicks, D., Sears, P., Gao, H., Goodmans, P. and Manning, J. (2004), 'Preparing tomorrow's teachers to be socially and ethically aware producers and consumers of interactive technologies', Contemporary Issues in Technology and Teacher Education, 3 (4), pp. 470-481.

19. Huang, R. (2005). 'Chinese International Students' Perceptions of the Problem-Based Learning Experience', Journal of Hospitality, Leisure, Sport and Tourism Education, 4 (2), pp. 36-43 [online: http://www.heacademy.ac.uk/assets/hlst/documents/johlste/vol4no2/0108.pdf; accessed 03.07.2010]

20. Kahn, P. and O'Rourke, K. (2004). Guide to curriculum design: enquiry-based learning. York: Higher Education Academy, Imaginative Curriculum Network [online: http://www.campus.manchester.ac.uk/ceebl/resources/guides/kahn_2004.pdf; accessed 09.06.2010].

21. Kirschner, Paul. A., Sweller, J. and Clark, Richard E. (2006). "Why minimal guidance during instruction does not work: an analysis of the failure of constructivist, discover, problem-based, experiential, and inquiry-based teaching". Educational Psychologist, 41 (2), 75-86.

22. Levy, P. (2007). "Exploring and developing excellence: towards a community of praxis". International Perspectives on Teaching Excellence in Higher Education, A. Skelton, ed. (London: Routledge), pp. 241256.

23. Levy, P. (2009). Inquiry-based learning: a conceptual framework (Sheffield: Centre for Inquiry-based Learning in the Arts and Social Sciences, University of Sheffield) [available online at: www.shef.ac.uk/ibl; accessed 23.06.2010].

24. Levy, P. and Petrulis, R. (forthcoming, 2012). "How do first-year university students experience inquiry and research, and what are the implications for the practice of inquiry-based learning?". Studies in Higher Education, 37 (1).

25. Mackinnon, Jacquelin (2006), 'Problem Based Learning and New Zealand Legal Education', Web Journal of Current Legal Issues [online at: http://webjcli.ncl.ac.uk/2006/issue3/mackinnon3.html; accessed 11.06.2010]. 
26. McKinney, P. and Levy, P. (2006), 'Inquiry-based learning and information literacy development: a CETL approach', ITALICS 5 (1) [Online at: http://www.ics.heacademy.ac.uk/italics/vol5iss2.htm; accessed 19.06.2010]

27. O'Kelly, Jackie (2005), 'Designing a hybrid problem-based learning (PBL) course: A case study of first year computer science in NUI, Maynooth', Handbook of Enquiry and Problem-Based Learning. Irish Case Studies and International Perspectives, T. Barrett, I. Mac Labhrainn and H. Fallon, eds. (Dublin: AISHE), pp. 45-53 [online: http://www.aishe.org/readings/2005-2/chapter5.pdf; accessed 19.06.2010].

28. Oates. B. J. (2006), Researching Information Systems and Computing. SAGE Publications

29. Pawson, E., Fournier, E. J., Haigh, M. J., Muniz, O., Trafford, S. and Vajoczki, S. (2006), 'Problem-based learning in geography: towards a critical assessment of its purposes, benefits and risks', Journal of Geography in Higher Education, 30 (1), 103-116.

30. Semmens, N. and Taylor, M. (2006), 'CILASS: promoting inquiry-based learning and information literacy', UK Centre for Legal Education Newsletter (Directions), spring. [Online at: http://www.ukcle.ac.uk/directions/previous/issue12/cilass.html; accessed 11.06.2010].

31. Smith, Alan (2003), 'Global Challenges for Citizenship Education', Active Global Citizenship, Wednesday 25 June 2003 [online at: http://www.Itscotland.org.uk/Images/globalchallenges_tcm4-121926.pdf; accessed 11.06.2010]

32. Smith, Martha M. (2002), Global Information Ethics: a mandate for professional education, 68th IFLA Council and General Conference August 18-24, 2002 [online at: http://archive.ifla.org/IV/ifla68/papers/056-093e.pdf; accessed 11.06.2010]

33. Stewart, D., Shamdasani. P, Rook. D, (2006) Focus Groups: Theory and Practice, Sage Publications

34. Vygotsky, L.S. (1962). Thought and Language. (Cambridge, MA: MIT Press).

35. Vygotsky, L.S. (1978). Mind in Society. (Cambridge, MA: Harvard University Press).

36. Wood, J and Levy, P. (2009), 'Inquiry-based learning pedagogies in the arts and social sciences: purposes, conceptions and approaches', Proceedings of the 16th Improving Student Learning Symposium (Oxford: Oxford Centre for Staff and Learning Development, 2009), pp. 128-142.

37. Woodcock, Leone (2000), 'Legal and Ethical Issues in Multimedia: A Technical Perspective', ASCILITE 2000 Conference [online at: http://www.ascilite.org.au/conferences/coffs00/papers/leone_woodcock.pdf; accessed 11.06.2010]. 